Int. J. Electrochem. Sci., 15 (2020) $6815-6828$

\title{
High Performance of MWCNTs - Chitosan Modified Glassy Carbon Electrode for Voltammetric Trace Analysis of Cd(II)
}

\author{
J. Calvillo Solís, M. Galicia* \\ Universidad Autónoma de Ciudad Juárez, Departamento de Ciencias Químico-Biológicas, C.P. 32300, \\ Juárez, CH. México. \\ *E-mail: monica.galicia@uacj.mx
}

doi: $10.20964 / 2020.07 .56$

Received: 3 March 2020 / Accepted: 22 April 2020 / Published: 10 June 2020

\begin{abstract}
A scaffold of multiwalled carbon nanotubes (MWCNT) and chitosan biopolymer were assembled on glassy carbon electrode (GCE) for Cadmium(II) ion detection in aqueous solution. The electrodes were characterized using cyclic voltammetry and electrochemical impedance spectroscopy. Parameters for the electrochemical detection of cadmium ions were optimized using Square Wave Anodic Stripping Voltammetry (SWASV), with an acetate buffer at a pH of 5. A limit of detection of $0.09 \mu \mathrm{g} \mathrm{L}^{-1}$ was achieved. Moreover, detection selectivity was demonstrated using SWASV with this modified electrode for $\mathrm{Cd}(\mathrm{II})$ detection in the presence of other toxic heavy metal ions, including $30 \mu \mathrm{g} \mathrm{L} \mathrm{L}^{-1} \mathrm{~Pb}(\mathrm{II}), 30 \mu \mathrm{g} \mathrm{L}$ ${ }^{1} \mathrm{Co}(\mathrm{II})$, and $100 \mu \mathrm{g} \mathrm{L}{ }^{-1} \mathrm{Hg}(\mathrm{II})$. This electrode combined with SWASV provides a new perspective for simultaneous detection of these species with a very low limit of detection.
\end{abstract}

Keywords: Anodic stripping voltammetry, glassy carbon electrode, MWCNTs, Trace analysis, Cd(II)

\section{$\underline{\text { FULL TEXT }}$}

(C) 2020 The Authors. Published by ESG (www.electrochemsci.org). This article is an open access article distributed under the terms and conditions of the Creative Commons Attribution license (http://creativecommons.org/licenses/by/4.0/). 